\title{
Conserving Latin American and Caribbean mangroves: issues and challenges
}

\author{
Ariel E. Lugo ${ }^{1}$
}

\begin{abstract}
This is a literature review of the distribution, salient features, uses, and conservation of mangroves in the Caribbean and Latin America. These ecosystems have played a vital role in the development of the region and their value increases as tropical countries develop and commercialize their coastal zones. Unfortunately, markets ignore or underestimate the value of products and non-market services from mangroves. Science informs and improves the effectiveness of the conservation of mangroves. Professional management with participation of all sectors of society also benefits the conservation of mangroves. Understanding mangrove ecosystems requires consideration of multiple spatial and temporal scales and attention to paradoxes that can lead to ineffective conservation measures. The review includes guidelines for mangrove restoration and conservation.

KEYWORDS:

Caribbean, Latin America, mangal, mangroves, restoration.
\end{abstract}

\section{RESUMEN}

Ésta es un revisión de la literatura sobre la distribución, las características sobresalientes, los usos y la conservación de los manglares en el Caribe y América Latina. Estos ecosistemas han desempeñado un papel vital en el desarrollo de la región, incrementando su valor conforme los países tropicales desarrollan y comercializan sus zonas costeras. Desafortunadamente, los mercados ignoran o subestiman el valor de los productos y los servicios no comerciales de los manglares. Las ciencias proporcionan información y contribuyen a mejorar la efectividad de la conservación de los manglares; el manejo profesional, con la participación de todos los sectores de la sociedad resultan también benéficos para la conservación de los manglares. El conocer a los manglares como ecosistemas requiere de la consideración de múltiples escalas espaciales y temporales, poniendo atención a las paradojas que pueden conducir a tomar medidas no efectivas para la conservación. Esta revisión incluye guías para la restauración y conservación de los manglares.

PALABRAS CLAVE:

Caribe, América Latina, mangal, manglares, restauración. 


\section{INTRODUCTION}

The conservation ${ }^{2}$ of mangroves -like the conservation of any ecosystem-requires and benefits from science. Unfortunately, scientific understanding of mangroves is incomplete in spite of the large amount of literature on this ecosystem (Chapman, 1976 and Rollet, 1981). The perceptions of mangroves in the literature evolved from scientific curiosity -trees adapted to seawater- to a focus on floristics, biogeography, and zonation of species. Today, mangrove research focuses on their functioning and importance to coastal productivity, fisheries, and coastal and global processes.

Latin American and Caribbean mangroves have sustained human activity since pre-Columbian times (Sanoja, 1992; Lacerda et al., 1993; Jiménez, 1994a), and continue to do so today (Lacerda, 1993; FAO, 1994; Windevoxhel, 1994). Early uses of mangroves posed no threat to them because the vast forested areas could absorb the low intensity subsistence use by dispersed human populations. Today, the demands on mangrove forests are more intensive and pervasive, and include conversion of mangroves to other uses and the urbanization of their uplands. The net effect on mangroves is the reduction of their area and the change in the conditions that regulate their functioning.

The trend in modern forest management practices is towards a holistic ecosystem approach with increasing emphasis on non-wood and non-market values of forests, which focuses on the needs of local people as well as those that utilize forests through markets. Mangroves are the paradigm of a forest ecosystem that produces market and non-market values through both wood and non-wood products (FAO, 1994). However, among the major ecosystems of
Latin America and the Caribbean, mangroves receive the least attention from conservation donors and agencies (Dinerstein et al., 1995). The lack of concern for this ecosystem has led to the loss of mangroves and overexploitation of dependent fisheries and other forest products. Therefore, while mangroves can serve people at local, regional, and global scales, mangrove conservation needs improvement so that human interaction with this ecosystem becomes an example to follow in the Homogeocene the era of human control of the world's ecosystems.

Much of the ecological research in mangroves has taken place in Latin America and the Caribbean (Lugo and Snedaker, 1974; Lacerda, 1993) including pioneer research on the geomorphology of mangrove coastlines (Thom, 1967). Rollet (1986) and Lacerda (1993) review available information on the mangroves of Latin America and the Caribbean and its relevance to conservation and sustainable use. Kjerfve et al. (1997), Kjerfve (1998), and Yáñez and Lara (1999) show recent mangrove studies in the region. The recent literature on mangrove systems throughout the Caribbean and Latin America is rich and diverse in focus (Table 1). In spite of all the research on mangroves, studies of the dynamics of mangrove ecosystems lag behind the need for new information for conserving these ecosystems, thus forcing users to act without full understanding of the risks and consequences of their actions.

Some people have argued that to properly conserve ecosystems, it is not necessary to conduct more research (e.g., Sheil, 2001), they think that all that is needed is to put into practice what we already know, and have the will to do "the right thing". There is a lot of truth to these statements as many human activities that affect natural resources ignore much of 
Table 1. Examples of recent studies of mangroves in Latin America and the Caribbean

\begin{tabular}{ll}
\hline LOCATION & SOURCE \\
\hline Belize & Feller et al., 1999 \\
Brazil & Academia de Ciéncias do Estado de São Paulo, 1987; \\
& Kjerfve and Lacerda, 1993; Gomes, 1997; de Castro, \\
& 2000; Pereira, 2000; Cunha, 2001. \\
Caribbean & Bossi and Cintrón, 1990; Bacon 1993; Milian et al., 1993. \\
Caribbean Coast of Colombia & Sánchez et al., 2000a. \\
Central America & Polanía, 1993; D’Croz, 1993; Polanía and Mainardi, \\
Colombia & 1993; Lacerda, 1993; Jiménez, 1994a and b. \\
Cuba & Alvarez, 1993; Cantera and Blanco, 2000; Blanco et al., \\
Ecuador & 2001. \\
Florida & Milian et al., 1993; Milian, 1997. \\
Mexico & Bodero, 1993. \\
Pacific Coast of Mexico & Odum, 1982; Chen and Twilley, 1999. \\
Perú & Kovacs et al., 2001b; Medina et al., 1995. \\
Puerto Rico & Flores et al., 1992. \\
Venezuela & Echevarría and Sarabia, 1993. \\
\hline
\end{tabular}

the information already stored in libraries. However, increasing human pressure on natural resources is resulting in new challenges to conservation because many large-scale processes come into play and we simply do not understand how these processes influence ecosystems or how we might mitigate or counteract their effects. We know that activities far removed from the mangroves affect them, but it is unlikely that humans will curtail land uses in the uplands of mangroves without accurate information about their cause-effect relationships with coastal processes. New research can inform society about risks and consequences of alternative land uses and natural resources management actions.

This essay is a brief review of the major challenges and strategies to the conservation of mangrove forests ${ }^{3}$. First, I review available literature on Latin American and Caribbean mangroves to define the extent, location, characteristics, and uses of these ecosystems. Then, I focus on their conservation based on the experience from Puerto Rico. Finally, I discuss eight paradoxes associated with mangrove ecosystems to assure effective conservation actions. 


\section{MANGROVE AREA, DISTRIBUTION, AND HIERARCHY}

The mangroves of Latin America and the Caribbean (including Florida) cover between 4.1 million of hectares (Lacerda et al., 1993) and 5.8 million of hectares (FAO, 1994) or about 30 to 35 percent of the world's total mangrove area. Cintrón Molero and Shaeffer Novelli (1992) report as latitudinal limits $32^{\circ} 20^{\prime} \mathrm{N}$ at Bermuda, and $28^{\circ} 30^{\prime} \mathrm{S}$ at Santa Clara, Santa Catarina, Brazil. This vast expanse of saltwater wetlands is diverse both in flora and fauna, as well as in the environmental settings on which they occur. According to Thom (1982) and Cintrón and Shaeffer (1992), mangroves grow in the following eight environmental settings:

- low tidal range with ample sediment inputs,

- high tidal range and sediment inputs,

- $\quad$ high wave energy and low sediment inputs,

- high wave energy and high river discharge,

- drowned river valley,

- low energy carbonate platforms,

- coral rampart or protective sand barrier, and

- low energy embayments without protective barriers.

Because of the complexity of the environmental settings, it is convenient to recognize a hierarchy of mangrove systems. I will arbitrarily use three levels of hierarchy, but there could be others. Mangal refers to the mangrove community (focus on the tree species), mangroves refers to the mangrove ecosystem (focus on all its biodiversity and function), and regional mangrove ecosystem refers to the structure, species composition, and functioning of all the coastal setting (focus on large-scale phenomena). This hierarchical concept of mangroves helps define their spatial boundaries and facilitates conservation activities.

\section{MANGROVE FLORA AND FAUNA}

The interface between the mangal and terrestrial habitats can be abrupt, particularly in dry life zones, leaving no question as to the limit of the mangrove environment, but it can also be gradual. Behind many mangals in moist and wet life zones, there is often a broad expanse of oligohaline (fluctuating salinity, usually below ocean strength) tidal wetland conditions where many wetland species with some salt tolerance grow in close proximity to the true mangroves (sensu Tomlinson, 1986). Examples of mangrove associate species are the tree Pterocarpus officinalis and the fern Acrostichum aureum. The listings of mangrove associated species for the Caribbean and Latin America are incomplete and less developed than their old world counterparts. Tomlinson (1986) summarized this argument initially presented by Gentry (1982). More recently, Jiménez (1994a) assembled a more comprehensive list of mangrove associates for Pacific Central America. He listed 34 species for this part of the world, while FAO (1994) listed some 82 mangrove associated species worldwide. Macro algal communities are also of interest in mangroves because they are common on mangrove roots and support aquatic food chains. Cordeiro et al. (1992) found a greater species richness of macro algae in the Caribbean (109 species) than in other regions of Latin America.

The fauna of Latin American and Caribbean mangroves is described for various mangrove areas in Odum (1982), López et al. (1988), Lacerda et al. (1993), Yáñez et al. (1993, 1994), Pauly and Yáñez (1994), Wunderle and Waide (1993, 1994), Lefebvre et al. (1994), Cruz and Jiménez (1994), and Jiménez (1994a). An emerging generalization from these studies is that the richness of nontree species in mangals, is many times higher than that of trees. For example, Szelistowski (1990) found 152 consumer 
species in the Punta Morales mangroves of Costa Rica, where the plant species component was about one order of magnitude less diverse. Alves et al. (1997) identified 34 avian species during four field trips to a mangrove stand $\left(4200 \mathrm{~m}^{2}\right)$ in Rio de Janeiro, while Naranjo (1997) reported 75 avian species in the Pacific coast mangroves of Colombia. In groups such as those of soil infauna, accounts overlook species in spite of their apparent importance to the functioning of mangroves. For example, dozens of species of deep burrowing macro crustaceans can occur in densities of up to hundreds of burrows $/ \mathrm{m}^{2}$, and can function as keystone species in some mangrove sediments but their taxonomic description is still rudimentary (Felder, 2001).

Another emerging generalization about the fauna of the mangal is that a large fraction of the respiration of mangrove productivity involves microbes and animals living outside the mangal, particularly in adjacent estuarine and marine waters (Odum, 1982; Twilley et al., 1992; Yáñez et al., 1993 and 1994, Pauly and Yáñez, 1994; FAO, 1994). Thus, the food webs of mangroves span a broad geographic range, reflecting the openness of this ecosystem and its many interactions with other coastal and montane ecosystems.

From a functional point of view, there are interconnections between mangals, estuarine waters, seagrass communities, coral reefs, mangrove lagoons, other marine ecosystems, floodplains, and montane communities (Twilley et al., 1992). All these communities contribute to marine, estuarine, and freshwater environments that harbor and feed complex food webs of organisms that extend into the open ocean and inland into freshwater montane and lowland floodplain habitats (Odum, 1982; Lugo, 1986; López et al., 1988; Yáñez et al., 1993 and 1994; Jiménez, 1994a). Mangals and other coastal wetlands absorb upland nitrogen inputs, and in so doing protect seagrass beds and reduce coastal eutrophication (Valiela and Cole, 2002). Migrant avian species use mangroves and connect them to faraway terrestrial systems (Wunderle and Waide, 1993 and 1994, Lefebvre et al., 1994).

\section{SALIENT FEATURES OF LATIN AMERICAN AND CARIBBEAN MANGROVES}

The mangroves of Latin America and the Caribbean exhibit wide variation in structural, functional, and physiognomic characteristics (Cintrón and Shaeffer, 1985; Rollet, 1986; Lacerda, 1993; Jiménez, 1994a; Sánchez et al., 2000a). The region itself has the appropriate climate, an abundance of fluvial systems, a tidal range from a few $\mathrm{cm}$ to over $5 \mathrm{~m}$, and gigantic river deltas with adequate substrates and inputs for mangrove growth. As a result, the mangroves of the region attain spectacular development, particularly on the major river deltas. Along the Yucatán Peninsula and in low islands such as the Bahamas and others in the Caribbean, mangroves grow in a carbonate setting (sensu Thom, 1982). In this setting, mangroves attain completely different physiognomies and structure (Lugo, 1981 and 1994; Trejo et al., 1993) and are nutrient limited (Feller et al., 1999). In arid coastal zones such as those of Perú, mangroves grow in desert and semi-desert life zones but survive because they receive runoff from wet life zones in the Andes Mountains located thousands of kilometers inland (Echevarría and Sarabia, 1993). Dry life zones in the Caribbean result in mangrove fringes with particular dynamics (Cintrón et al., 1978; Lugo, 1990). In high-energy coastlines, mangroves grow behind sand dunes and receive salt and freshwater through ground water.

The presence of mangroves correlates with the presence of rich commercial fisheries, including shrimp (Odum, 1982; Turner, 1989). Luna (1976 and 1983) documented the commercial forestry potential of Venezuelan 
mangroves along the San Juan River. Studies consistently show the mangroves of Latin America and the Caribbean to be highly productive in terms of wood, biomass, and litter production and organic carbon export (Twilley et al., 1992; Cintrón, 1987).

\section{USES AND ABUSES OF LATIN AMERICAN MANGROVES}

There are case studies of both wise and poor uses of mangroves in Latin America and the Caribbean. Among successful examples, the use of the Caroni Swamp in Trinidad for tourism is notable (Bacon, 1970; Blohm and Pannier, 1989). The clear-cut harvesting for wood from mangroves of the San Juan River in Venezuela some 30 years ago, resulted in economic profit without inhibiting the regeneration of stands (Luna, 1976 and 1983; Hamilton and Snedaker, 1984). In that same mangrove forest, oil exploration appears to co-exist with the mangroves, although I have observed needless destruction of mangroves due to improper precautions in the handling of river dredging. Puerto Rico and Florida have superb examples of mangrove uses for touristic, recreational, educational, and scientific research activities, i.e., the Everglades and Rookery Bay forests in Florida; and the Jobos Bay, Piñones, and the El Faro of Fajardo mangroves in Puerto Rico. The commercially successful shrimp fishery in the Gulf of Mexico, and the artesanal use of mangroves for biomass energy (fuelwood) and fish protein throughout Latin America, are also examples of sustainable uses of mangrove ecosystems (Windevoxhel, 1994; Dinerstein et al., 1995).

In contrast to the examples given above, the conversion of the mangroves to shrimp ponds in Ecuador deserves attention. For this discussion, I use the accounts of Olsen and Arriaga (1989), and Twilley (1989). Ecuador has been successful in increasing shrimp exports at substantial profit and acquisition of hard currency for its economy. In 1987, shrimp export was second only to petroleum exports and netted US\$383 million to Ecuador's economy. This value had increased to US\$ 482 million by 1991 when Ecuador became the second leading shrimp producer in the world (Twilley et al., 1993). Because of Ecuador's economic success with shrimp aquaculture, other countries in the region, e.g., Honduras, Nicaragua, and Panama (Suman, 1994; Jiménez, 1994a; Osorio, 1994), stepped up efforts to establish aquaculture ventures in the production of shrimp for export. These ponds, usually located on mangrove forests and salt flats, require the conversion of mangroves and salt flats into open water ponds.

Shrimp pond construction accounted for the conversion of over a thousand hectares per year of mangrove forests in Ecuador over a period of 10 years. In some sectors of the coast, shrimp ponds replaced all mangroves. The total area of authorized ponds by 1988 was 118304 ha of which 90000 ha were in production. About 14 percent of Ecuador's mangroves became shrimp ponds between 1969 and 1978. Twilley et al. (1998a) report an additional reduction of over 40000 ha of salt flats between 1969 and 1991 .

How sustainable is the economic success of Ecuador's shrimp production ventures? The key to sustainability is the degree to which profits from the conversion of mangroves and salt flats to shrimp ponds compensate for the loss of ecological services to people and the shrimp industry. Unfortunately, ignoring the losses to indigenous peoples (i.e., local fisheries, fuelwood, tannin extraction, etc.) has been the rule, and the Ecuador situation is no exception to this rule. Most analyses focus only on the shrimp industry and ignore other sectors of society. Ecologists do likewise by focusing mostly on mangals and ignoring the greater mangrove ecosystem along with its salt flats.

At present, the following ecological factors appear to slow down shrimp 
productivity due to lack of sustainability in the overall enterprise:

- loss of water quality;

- more red tide events;

- high mortality of organisms inside and outside ponds, including shrimp, and loss of feeding, roosting, and nesting habitats for birds;

- shortage of cheap natural supplies of post larvae and food to seed and feed the ponds;

- $\quad$ reduction in the wild shrimp fishery; and

- high proportion of ponds out of production.

Non-productive ponds represent a double loss because not only is their shrimp production lost, but also lost are the benefits of the mangroves and salt flats they replaced. Expensive rehabilitation efforts will be required to restore the mangroves because of the changes in the geomorphology and hydrology of sites (Lugo, 1999b).

In summary, the gamble of converting mangrove forests and salt flats to shrimp ponds is that a sustainable resource with multiple values is converted to a system with a single output and a potentially high but possibly short-term economic payoff, with equally high management costs and risk of failure. If the ponds fail, the region will be without shrimp and the values that it previously extracted from mangroves and salt flats. Moreover, mangroves and salt flats no longer exist. Indigenous populations and the government must deal with the long-term cost of these operations. If the shrimp ponds are successful in the long-term, profits to the industry can improve the life quality of people, assuming that profit distribution and sound investments take place.

Many tropical countries face the Ecuadorian trade off between resource preservation and use. On one extreme are the low risk of failure and low market economic output but high non-market value of mangrove ecosystems (Winde- voxhel, 1994). On the other extreme, are the high economic gain, high maintenance cost, and high risk of failure of the converted mangrove lands (Olsen and Arriaga, 1989; Twilley et al., 1998a). Conversions of mangrove forests can also be to pastures, agricultural fields, housing, marinas, or tourism developments (Suman, 1994; Jiménez, 1994a; Aguilar, 1994; Osorio, 1994; Sánchez et al., 2000a). However, this dichotomy is artificial because preserving mangroves can also result in risk and degradation.

Poorly conducted artesanal
exploitation can degrade mangroves (Jiménez, 1992; 1994a and b). Uncontrolled human activity pollutes and degrades mangroves, and converts them into garbage dumps or to other uses as population density increases in the vicinity (Sánchez et al., 2000a). Many mangrove reserves in Central America become degraded after their proclamation as reserves because there were no efforts to delimit, manage, and protect them (Suman, 1994). Even worse, as countries develop their infrastructure of roads, water works, electric or telephone transmission lines, etc., they impact and harm mangrove ecosystems. These negative effects occur by changing the inputs of freshwater, sediments, and nutrients, documented in the Caribbean Colombia by Sánchez et al. (2000a) and Venezuela by Medina et al. (2001). Many government officials erroneously consider freshwater discharge to mangroves and estuaries as a "waste of freshwater". Therefore, poor understanding of coastal ecology in combination with events that take place far from the mangroves, can greatly affect the function of the regional mangrove ecosystem. Moreover, by not understanding the value of mangroves, construction of infrastructure occurs inside the mangroves, fragmenting their structure and function, and limiting their capacity to serve people.

Slowly, Latin American and Caribbean countries are developing laws and regulations to protect mangroves 
(Suman, 1994; Lacerda, 1993; Sánchez et al., 2000a). However, these laws, like the conservation of mangroves, are fragmented and their enforcement is non-existent. Moreover, the laws, regulations, and conservation actions all lack the holism required to conserve the greater mangrove ecosystem.

Clearly, a gigantic leap forward is required to advance the paradigms of regulation and conservation of tropical coastal ecosystems. First, countries have to realize the value of their coastal ecosystems and consider the non-market as well as the market benefits of these resources. Mangroves are assets as important as cash reserves. Like money, mangroves require proper management to yield the full realm of benefits to society. Colombia is an example of a country with a strategic plan for the sustainable management of its mangroves (Sánchez et al., 2000b).

Next, countries need to devise strategies for protecting the products, services, and profits derived from coastal ecosystems. Many indigenous and urban populations derive benefits from mangroves but such gains are rarely accounted in costbenefit analyses of developments. For development strategies to be inclusive and lead to sustainability, it is necessary to consider and value all sectors of society and all natural ecosystems.

Finally, countries need to design laws, regulations, institutions, and conservation styles that are ecologically, socially, culturally, and economically relevant. Consideration to all values or points of view is necessary in the planning stages of natural resource conservation. Long-term sustainability of the natural resource base is a necessary objective to keep in mind when facing the inevitable tradeoffs that accompany conservation activity. Society requires a full spectrum of products and services from its natural ecosystems but if it fails to invest in proper ecosystem conservation, it will eventually pay for the consequences of poor use of resources. Therefore, conservation of natural assets requires prudence. The ultimate solution rests on the realization that success, measured as sustainability of mangrove function, is neither found in absolute preservation nor in total annihilation of the natural resource base. Success occurs by seeking balances between the interests of people and the capacity of ecosystems to function and deliver value for generations.

\section{RESTORING AND CONSERVING MANGROVES}

Dinerstein et al. (1995) assessed the status of all mangroves in Latin America and the Caribbean using a consistent protocol. First, they identified 13 mangrove complexes in the region and subdivided these into 40 smaller units or segments (Fig. 1). They then evaluated the conservation status of each unit in terms of loss of habitat, large blocks of intact habitat, water quality and hydrographic integrity, rate of habitat conversion, degree of protection, degree of fragmentation, and degree of alteration of the catchement basin. They found that 13 percent of the mangrove units were stable and 38 percent were either critical or endangered. Twenty units qualified for conservation with restricted access, and 29 units qualified for conservation with sustainable use. Seventeen units qualified under two or more activities. The most appropriate conservation activity for nine mangrove units was restoration. This raises the question of the available experience with restoration of mangroves.

Sánchez et al. (2000a) documented a large-scale restoration program for mangroves in Colombia. Restoration projects accounted for about 1000 ha in eight departments of the Caribbean coast of that country. The objective was to reverse the degradation of mangrove forests, which had reached 13.7 percent of the total mangrove area. The literature contains reports of other restoration efforts 


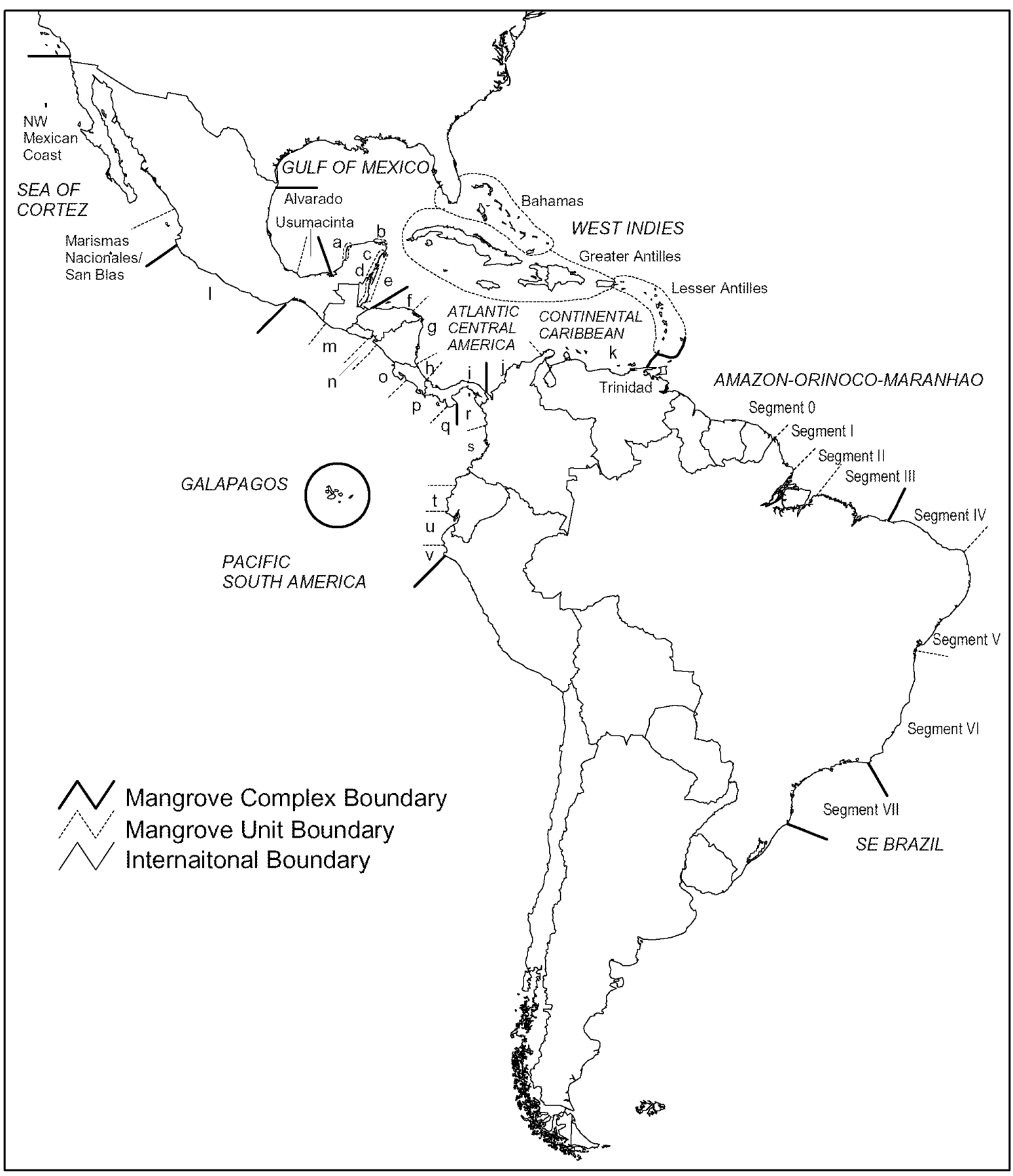

Figure 1. Mangrove complexes and units of Latin America and the Caribbean (Dinerstein et al., 1995).

Key: Yucatán Complex: a. Petenes; b. Río Lagartos; c. Mayan Corridor; d. Belizean Coast; e. Belizean Reef; f. Northern Honduras; g. Mosquitia/Nicaraguan Caribbean Coast; h. Río Negro/Río San Sun; i.Bocas del Toro/ Bastimentos Island/San Blas. Continental Caribbean Complex: j. Magdalena/Santa María; k. Coastal Venezuela. Pacific Central American Complex: I. Tehuantepec/El Manchón; n. Northern Dry Pacific Coast; 0. Southern Dry Pacific coast; p. Moist Pacific Coast; q. Panama Dry Pacific. Pacific South America Complex: r. Gulf of Panama; s. Esperaldas/Pacific Colombia; t. Manabi; u. Gulf of Guayaquil/Tumbes. v. Piura.

Segment numbers identify different regions of Brazilian mangroves. 
in Colombia (del Rosario and Bohorquez, 1997), Florida (Snedaker and Biber, 1997), Panama (Duke, 1997), and elsewhere in the world (Field and Trauman, 1997). While the restoration of the mangal is fairly straight-forward and generally successful (Lugo, 1999b), it is not known how long is required for restored mangals to develop the large diversity of fauna associated with soil and sediments. An open research question is the degree to which soil, sediments, and soil infauna return to a functional status after the restoration of mangrove trees to damaged sites.

On Caribbean islands such as Puerto Rico, the area of mangroves decreased to less than half their original range. Public concern for mangrove conservation followed their conversion to other uses, and this concern resulted in the rehabilitation of some mangrove forests through protection. Mangroves that once were garbage dumps, housing developments, or agricultural fields, are now pristine-looking forests (Plates). I have observed these forests recover, and developed the following list of strategies for the conservation of mangroves near developed lands.

- Maintain the natural supplies of freshwater, nutrient, and sediments as well as the normal hydroperiod of the mangroves.

- Maintain the original hydrologic regime as much as possible.

- Avoid locating roads, dikes, or other structures in alignments that interrupt water flow to and from mangrove forests.

- Allocate as much space as possible for the expansion of the mangroves.

- Don't change the landforms that support mangrove forests, i.e., avoid destroying dunes, filling swamps, dredging channels, or changing the shape of the land.

- Avoid excessive sedimentation, heating, poisoning, filling, or oilcoating mangroves.
- Maintain sand dunes, sand bars, and coral reefs, which protect mangroves from excessive wave action.

- Strive for management strategies that result in multiple uses and outputs from mangroves, avoiding single use schemes.

- When conducting cost-benefit analysis, always consider local uses and non-market values of mangroves and the contributions of mangroves to up- and downstream ecological processes.

These simple rules of development contribute to the survival of mangroves and ensure sustainable productivity. In return, mangroves will deliver indefinitely and free of cost, products and services to people.

\section{DEALING WITH THE PARADOXES OF MANGROVE ECOLOGY AND VALUES}

The conservation of natural resources is a contentious activity. With economic pressures for development at all costs, environmentally unfriendly economic paradigms such as neoliberal economics (Lugo, 1996), and the low priority given to conservation in most governments, all conspire to resource exploitation and degradation. Objective science information enlightens the debate and uncovers options. It is also useful to clarify public discussion. When dealing with mangroves, one uncovers many apparent paradoxes that require attention if mangrove conservation is going to be effective. I end this essay with a listing of some of these paradoxes.

Mangroves are simple ecosystems of great complexity. A monospecific mangal is a simple forest compared to a multispecies rain forest. Yet, the simplicity of the mangal is deceiving. The complexity of the mangrove ecosystem is not obvious to the casual observer. Mangroves are hydrologically complex ecosystems. Tides, 


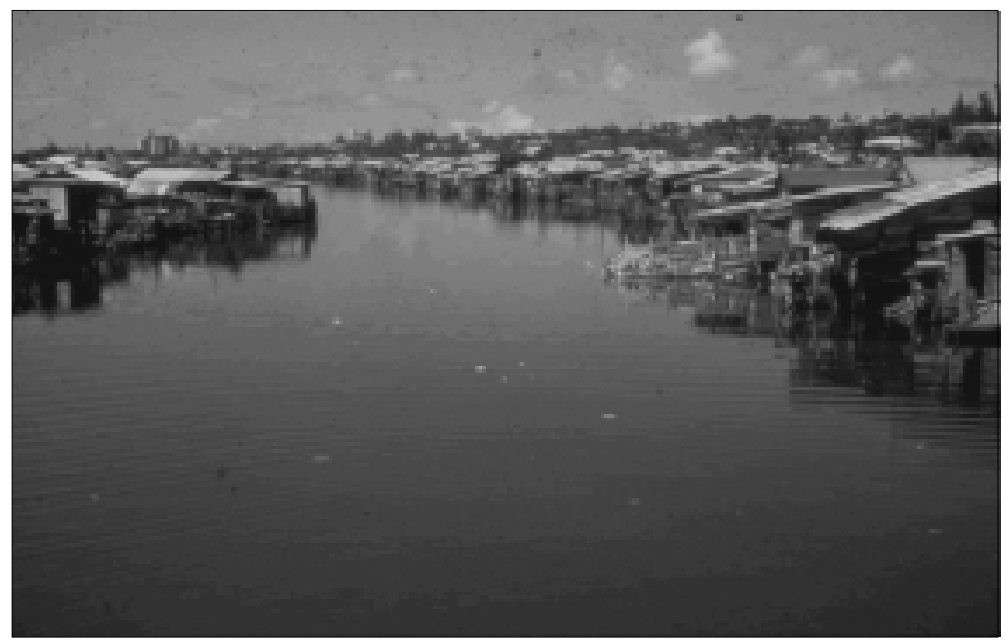

(a)

(b)

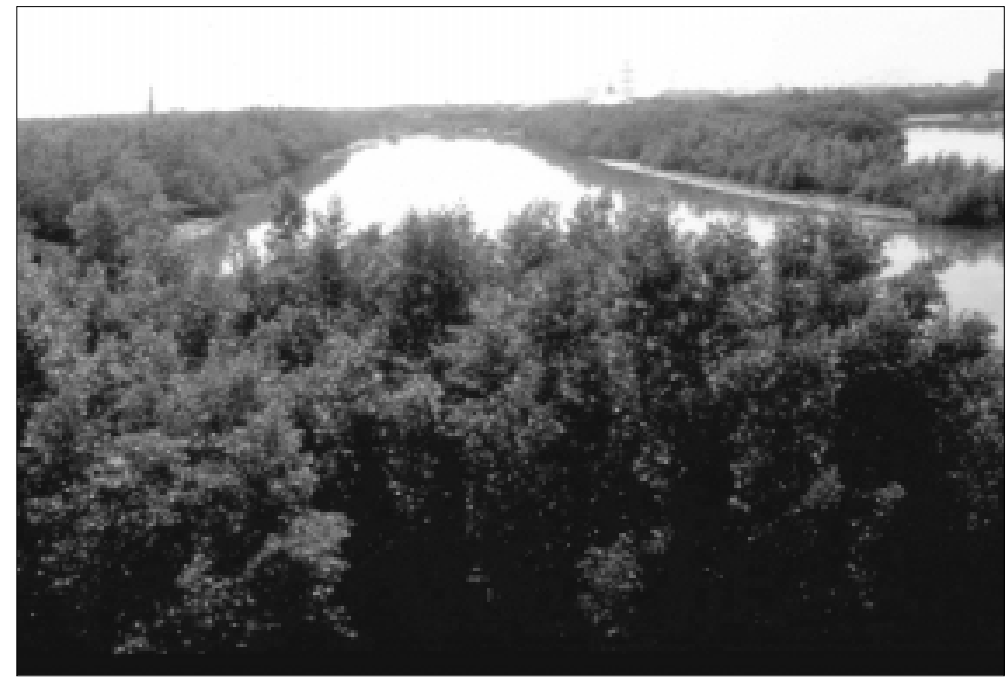

(c)

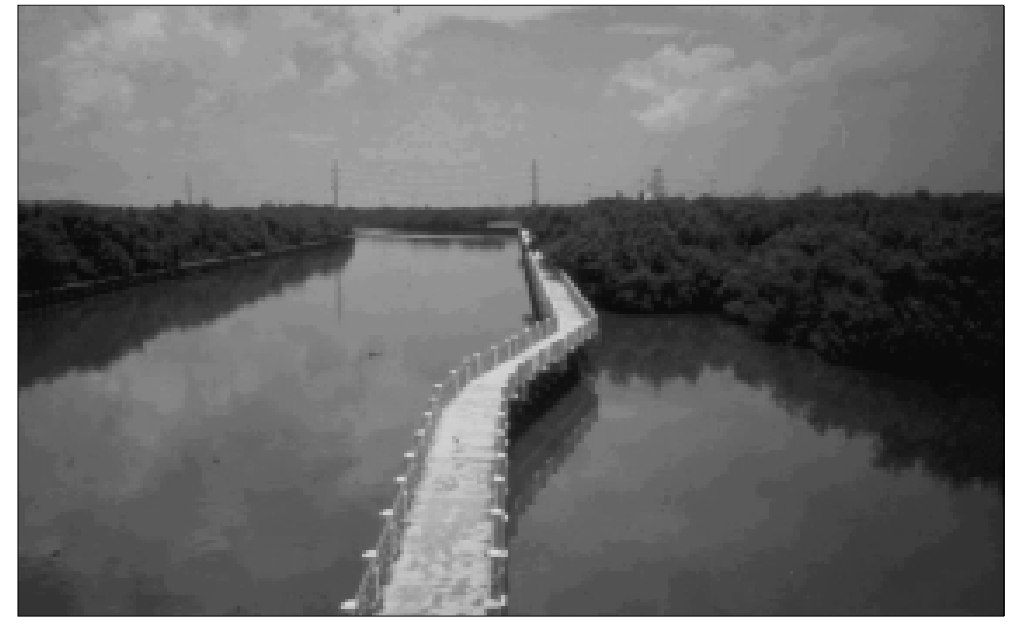

Plates. Three pictures of a mangrove forest located in the Metropolitan Area of San Juan, Puerto Rico. The forest has undergone dramatic change from the time it was converted to housing in the 1970's (a), a successional mangrove forest in the 1980's (b), and a mature mangrove stand in 1995 (c). (Photos by A.E. Lugo). 
overland runoff, sheet flow, and aquifer discharges are some of the external water flows and kinetic energies that converge on these forests. In addition, mangroves harbor in its sediments the interface of aerobic and anaerobic processes, each with its own complement of microbial species. The biota of mangrove substrates is complex and largely unknown, and we do not understand the complex food webs that converge on mangrove ecosystems. Finally, mangroves are open systems with significant exchanges of materials and organisms with ecosystems in terrestrial, oceanic, estuarine, and atmospheric environments. The study of such high levels of complexity is only beginning, as most of the literature focused on the simplicity of the aboveground arboreal component of this ecosystem.

\section{Mangrove forests are mature ecosys- tems dominated by pioneer species.} This assertion is both paradoxical and partially a myth (Lugo, 1980). The paradox is that pioneer species dominate some mature phases of mangrove succession. The classic example in the Caribbean and Latin America is Rhizophora mangle. Part of the explanation is the fact that dispersal and fast colonization capabilities are favorable traits for survival in the landocean interface, which coupled with the harshness of the environment, leads to few species as capable of occupying the seaward part of the mangrove zonation. This explains the coincidence of the pioneer nature of the dominant species in a mature forest. However, the statement is partially a myth, because mangrove species do succeed each other when zonations are disturbed, as is the case of Laguncularia racemosa invading a red mangrove zone for short time periods (Twilley et al., 1998b).

Mangroves are highly productive but they can die in a very short time period. Emphasis on the high productivity of mangroves is common, but their high rate of mortality receives less attention.
Mangroves grow and die fast (Jiménez et al., 1985). A possible explanation for this is that the harshness of the mangrove environment can support a given rate of productivity provided it remains constant. However, as soon as conditions change, the cost of survival is too high and massive mortality occurs almost instantaneously. High rates of mortality in mangroves occur when salinity exceeds certain thresholds, with the interruption of oxygen supply to roots -by oil or changes in water fluxes- or when high water temperatures kill roots.

Mangroves are resilient and vulnerable. Because of their high productivity and pioneer species characteristics, mangrove trees exhibit high resilience after disturbances (Lugo et al., 1981). For example, they re-grow rapidly after floods, hurricanes, or even frost. However, the mangrove forest is vulnerable to changes in hydrologic fluxes, sedimentation, changes in temperature, and modification of topography. Favorable mangrove conditions assure resilience; when natural or anthropogenic events change conditions, mangrove vulnerability is exposed (Lugo et al., 1981).

Mangroves are vital to humans, but many times, they are not valued. Mangroves are among the few natural ecosystems whose economic value is relatively easy to demonstrate. The production of such commercially important products as wood, charcoal, tannins, protein, or honey make them economically important and vital to some economies. However, to land developers or acuaculturists, mangrove sites are more profitable if converted to built up land or for culturing shrimp. It is ironic that the economic success of shrimp culture depends on larvae from the mangrove environment. However, shrimp culture pond construction destroys mangroves in large areas of South America. Ecological analyses are part of economic evaluation and represent an insurance for avoiding 
the squandering of vital resources (e.g., Twilley et al., 1998a).

Consulting local users of mangroves is useful for planning coastal development, but local perceptions may not match reality. Kovacs (1999) found that the perceptions of the traditional users of mangroves in Mexico did not fit the reality of actual use of the resource. Large-scale anthropogenic changes in the region plus passage of a hurricane were reasons for the change in the pattern of use of mangroves (Kovacs, 2000). He also found that anthropogenic change had greater impact on the resource than hurricane passage. While it is clear that mangrove conservation benefits from consulting local people, their perceptions need to be validated and placed in context based on sound analysis of the conditions of the resource and its environmental setting (e.g., Twilley et al., 1998a).

As economic development progresses, humans discontinue direct uses of mangroves, but the value of mangroves increases. The direct traditional uses of mangroves decline with economic development of regions. For example, their use for lumber charcoal, tannins, and local fisheries disappear in portions of their range where development becomes more urbanized. In addition, changes in the mangrove forests can lead to changes in the use patterns (Kovacs, 1999). Examples of these trends occur in Florida, Puerto Rico, and portions of Mexico. Yet, in these areas, the value of mangroves increases due to the higher multiplier value of the services provided by mangroves. Clean water, panorama, refugia for biodiversity, recreation, and tourism are but a few of the services that mangroves are valued for in developed countries. Should the services of mangroves be lost, the economic losses are greater than when the mangroves were only valued for local subsistence purposes.
In a modern context, the conservation of local mangrove stands requires attention to regional or global level processes. Because of their coastal location and open system functioning, mangrove forests respond to a suite of factors whose control is far from the coast. Mangroves respond to natural disturbances that originate far at sea (hurricanes) or inland far from the mangroves (freshwater runoff and sedimentation). Many times mangroves experience regional-scale changes in structure or composition that are difficult to interpret because causal factors are not obvious (Kovacs et al., 2001a). Currently, sea level rise -a global phenomenon- is critically affecting coastal forests all over the world (Barnett, 1982; De Silva, 1986; Williams et al., 1999; Boesch et al., 2000). Even more important for the conservation of mangroves, human activities that affect the fluxes of nutrients, sediments, water, tides, or organisms, become critical to the functioning and survival of mangrove ecosystems. In short, the conservation of mangroves is becoming more complicated because it requires attention to all the processes that impinge on the coastal system and we are learning that these processes involve the full gamut of human activity from local to global scales.

\section{ACKNOWLEDGMENTS}

This work is in cooperation with the University of Puerto Rico. I thank Carlos Domínguez Cristóbal and Grizelle González for their suggestions to improve the manuscript. Mildred Alayón assisted in the production of the manuscript.

\section{LITERATURE CITED}

Academia de Ciéncias do Estado de São Paulo. 1987. Simposio sobre ecosistemas da costa sul e sudeste Brasileira: síntese dos conhecimentos. Cananéia, Brazil. 
Aguilar R., X. 1994. CODDEFFAGOLF: los defensores de los manglares del Golfo de Fonseca, Honduras. Revista Forestal Centroamericana 3(9): 27-32.

Álvarez L., R. 1993. Mangrove ecosystems of Colombia. In: Lacerda, L.D., Project Coordinator. Conservation and sustainable utilization of mangrove forests in Latin America and Africa regions. International Society for Mangrove Ecosystems and International Tropical Timber Organization Project PD114/90(F). Yokohama, Japan. p: 75-113.

Alves, V.S.; A.B.A. Soares, and A.B.B. Ribeiro. 1997. Birds of the Jequia mangrove system, llha do Governador, Baía de Guanabara, Rio de Janeiro, Brazil. In B. Kjerfve, L.D. de Lacerda, and E.H.S. Diop, eds. Mangrove ecosystem studies in Latin America and Africa. United Nations Educational, Scientific and Cultural Organization, Paris, France. p: 163170.

Bacon, P.R. 1970. The ecology of the Caroni Swamp, Trinidad. Central Statistical Office. Trinidad. 68 p.

Bacon, P.R. 1993. Mangroves in the Lesser Antilles, Jamaica and Trinidad and Tobago. In: Lacerda, L.D., Project Coordinator. Conservation and sustainable utilization of mangrove forests in Latin America and Africa regions. International Society for Mangrove Ecosystems and International Tropical Timber Organization Project PD114/90(F). Yokohama, Japan. p:155-209.

Barnett, T.P. 1982. On possible changes in global sea level and their potential causes. DOE/NBB-0022, UC-11, TR001. U.S. Department of Energy. Office of Energy Research. Office of Basic Energy Sciences. Carbon Dioxide Research Division. 36 p.
Blanco, J.F.; A.C. Bejarano; J. Lasso, and J.R. Cantera. 2001. A new look at computation of the complexity index in mangroves: do disturbed forests have clues to analyze canopy height patchiness? Wetlands Ecology and Management 9:91-101.

Blohm, C. and F. Pannier. 1989. Manglares. Editorial Ex Libris. Caracas.

Bodero, A. 1993. Mangrove ecosystems of Ecuador. In: Lacerda, L.D., Project Coordinator. Conservation and sustainable utilization of mangrove forests in Latin America and Africa regions. International Society for Mangrove Ecosystems and International Tropical Timber Organization Project PD114/90(F). Yokohama, Japan. p:55-73.

Boesch, D.F.; J.C. Field, and D. Sccavia, eds. 2000. The potential consequences of climate variability and change on coastal areas and marine resources. NOAA Coastal Program Decision Analysis Series No. 21. US Department of Commerce. Silver Spring, MD. 163 p.

Bossi, R. and G. Cintrón. 1990. Mangroves of the wider Caribbean. Caribbean Conservation Association. The Panos Institute and United Nations Environment Programme. Nairobi, Kenya. 33 p.

Cantera, J.R. and J.F. Blanco. 2000. The estuary ecosystem of Buenaventura Bay. Colombia. Ecological Studies 144:265-280.

Chapman, V.J. 1976. Mangrove vegetation. Valduz. Cramer.

Chen, R. and R.R. Twilley. 1999. A simulation model of organic matter and nutrient accumulation in mangrove wetland soils. Biogeochemistry 44:93-118. 
Cintrón, G. 1987. Caracterización y manejo de áreas de manglar. In: Academia de Ciéncias do Estado de São Paulo. Simposio sobre ecosistemas da costa sul e sudeste Brasileira: síntese dos conhecimentos. Cananéia, Brazil. p:77-97.

Cintrón, G.; A.E. Lugo; D.J. Pool, and G. Morris. 1978. Mangroves of arid environments in Puerto Rico and adjacent islands. Biotropica 10: 110-121.

Cintrón, G. and Y. Shaeffer N. 1985. Características y desarrollo estructural de los manglares de Norte y Sur América. Ciencia Interamericana 25:4-15.

Cintrón M., G. and Y. Shaeffer N. 1992. Ecology and management of new world mangroves. Pages 233-258. In: U. Seeliger, ed. Coastal plant communities of Latin America. Academic Press, Inc. San Diego, CA.

Conde, J.E. and C. Alarcón. 1993. Mangroves of Venezuela. In: Lacerda, L.D., Project Coordinator. Conservation and sustainable utilization of mangrove forests in Latin America and Africa regions. International Society for Mangrove Ecosystems and International Tropical Timber Organization Project PD114/90(F). Yokohama, Japan. p: 211-243.

Cordeiro M., M.; M.R.A. Braga; V.R. Eston; M.T. Fujii, and N.S. Yokona. 1992. Mangrove macroalgal communities of Latin America: the state of art and perspective. In: U. Seeliger, ed. Coastal plant communities of Latin America. Academic Press, Inc. San Diego, CA. p: 51-64.

Corredor, J.E.; J.M. Morell, and J. Bauza. 1999. Atmospheric nitrous oxide fluxes from mangrove sediments. Marine Pollution Bulletin 38:473-478.
Cruz S., R.A. and J.A. Jiménez. 1994. Moluscos asociados a las áreas de manglar de la Costa Pacífica de América Central. Editorial Fundación UNA. Heredia, Costa Rica. 182 p.

Cunha L., M. 2001. Dinâmica do manguezal no sistema de CananéiaIguape, Estado de São Paulo-Brasil. Thesis, Oceanographic Institute of the University of São Paulo, Brazil. $105 \mathrm{p}$.

D'Croz, L. 1993. Status and uses of mangroves in the Republic of Panama. In: Lacerda, L.D., Project Coordinator. Conservation and sustainable utilization of mangrove forests in Latin America and Africa regions. International Society for Mangrove Ecosystems and International Tropical Timber Organization Project PD114/90(F). Yokohama, Japan. p:115-127.

De Castro P., J.A. 2000. Caracterização da planície hipersalina (apicum) associada a um bosque de mangue em Guaratiba, Baía de Sapetiba, Rio de Janeiro-RJ. Thesis. Oceanographic Institute of the University of São Paulo, Brazil. 101 p.

De Silva, D.P. 1986. Increased storms and estuarine salinity and other ecological impacts of the "Greenhouse effect". Pages 153-164. In: J.G. Titus, ed. Effects of changes in stratospheric ozone and global climate. Volume 4. Sea level rise. U.S. Environmental Protection Agency. Washington, D.C.

Del Rosario, C. and C. Bohorquez. 1997. Restauración de manglares en Colombia. In: C. Field and D.B. Trauman, editor and translator. La restauración de ecosistemas de manglar. Organización Internacional de Maderas Tropicales y Sociedad Internacional Para Ecosistemas de Manglar. Editorial de Arte. Managua, Nicaragua. p:209-217. 
Dinerstein, E.; D.M. Olson; D.J. Graham; A.L. Webster; S.A. Primm; M.P. Bookbinder, and G. Ledec. 1995. A conservation assessment of the terrestrial ecoregions of Latin America and the Caribbean. World Wildlife Fund and World Bank. Washington, DC. $129 p+$ maps.

Duke, N. 1997. Reforestación de manglares en Panama. In: C. Field and D.B. Trauman, editor and translator. La restauración de ecosistemas de manglar. Organización Internacional de Maderas Tropicales y Sociedad Internacional para Ecosistemas de Manglar. Editorial de Arte. Managua, Nicaragua. p:231-258.

Echevarría, J. and J. Sarabia. 1993. Mangroves of Perú. In: Lacerda, L.D., Project Coordinator. Conservation and sustainable utilization of mangrove forests in Latin America and Africa regions. International Society for Mangrove Ecosystems and International Tropical Timber Organization Project PD114/90(F). Yokohama, Japan. p:43-53.

FAO (Food and Agriculture Organization). 1994. Mangrove forest management guidelines. FAO Forestry Paper 117. Rome, Italy. 319 p.

Felder, D.L. 2001. Diversity and ecological significance of deep-burrowing macrocrustaceans in coastal tropical waters of the Americas (Decapoda: thalassinidea). Interciencia 26:440-449.

Feller, I.C.; D.F. Whigham; J.P. O'Neil, and K.L. Mckee. 1999. Effects of nutrient enrichment on within-stand cycling in a mangrove forest. Ecology 80:2193-2205.

Field, C. and D.B. Trauman 1997. La restauración de ecosistemas de manglar. Organización Internacional de Maderas Tropicales y Sociedad
Internacional para Ecosistemas de Manglar. Editorial de Arte. Managua, Nicaragua. $278 \mathrm{p}$.

Flores V., F.; F. González F.; D.S. Zamorano, and P. Ramírez G. 1992. Mangrove ecosystems of the Pacific Coast of Mexico: distribution, structure, litterfall, and detritus dynamics. In: U. Seeliger, ed. Coastal plant communities of Latin America. Academic Press, Inc. San Diego, CA. p:269-288.

Gentry, A.H. 1982. Phytogeographic patterns as evidence for a Choco refuge. In: G.T. Prance, ed. Biological diversification in the tropics. Columbia University Press. New York. p:112-136.

Gomes S., M.L. 1997. Estudo da biomassa aérea de manguezais do sudeste do Brasil - análise de modelos. Dissertation. Oceanographic Institute of the University of São Paulo. São Paulo, Brasil. 2 volumes.

Hamilton, L.S. and S.C. Snedaker, eds. 1984. Handbook for mangrove area management. United Nations Environment Programme and EastWest Center. Environment and Policy Institute. Hawaii, USA. 123 p.

Jiménez, J.A. 1994a. Los manglares del Pacífico Centroamericano. Editorial Fundación UNA. Heredia, Costa Rica. 336 p.

Jiménez, J.A. 1994b. Bosques de manglares en la Costa Pacífica de América Central. Revista Forestal Centroamericana 3(9):13-17.

Jiménez, J.A. 1992. Mangrove forests of the Pacific Coast of Central America. In U. Seeliger, ed. Coastal plant communities of Latin America. Academic Press, Inc. San Diego, CA. p: 259-267. 
Jiménez, J.A., A.E. Lugo, and G. Cintrón. 1985. Tree mortality in mangrove forests. Biotropica 17(3):177-185.

Kjerfve, B., ed. 1998. Caribbean coral reef, seagrass, and mangrove sites. UNESCO. Paris, France. 345 p.

Kjerfve, B.; L.D. de Lacerda, and E.H.S. Diop, eds. 1997. Mangrove ecosystem studies in Latin America and Africa. United Nations Educational, Scientific and Cultural Organization. Paris, France. $349 \mathrm{p}$.

Kjerfve, B.J. and L.D. de Lacerda. 1993. Mangroves of Brazil. In: Lacerda, L.D., Project Coordinator. Conservation and sustainable utilization of mangrove forests in Latin America and Africa regions. International Society for Mangrove Ecosystems and International Tropical Timber Organization Project PD114/90(F). Yokohama, Japan. p:245-272.

Kovacs, J.M. 1999. Assessing mangrove use at the local scale. Landscape and Urban Planning 43:201-208.

Kovacs, J.M. 2000. Perceptions of environmental change in a tropical coastal wetland. Land Degradation and Development 11:209-220.

Kovacs, J.M.; J. Wang, and M. Blanco C. 2001a. Mapping disturbances in a mangrove forest using multi-date Landsat TM imagery. Environmental Management 27:763-776.

Kovacs, J.M.; M. Blanco C., and F. Flores V. 2001b. A logistic regression model of hurricane impacts in a mangrove forest of the Mexican Pacific. Journal of Coastal Research 17:30-37.

Lacerda, L.D., Project Coordinator. 1993. Conservation and sustainable utilization of mangrove forests in Latin America and Africa regions. International Society for Mangrove Ecosystems and International
Tropical Timber Organization Project PD114/90(F). Yokohama, Japan. $272 \mathrm{p}$.

Lacerda, L.D.; J.E. Conde; P.R. Bacon; C. Alarcón; L. D’Croz; B. Kjerfve; J. Polonía, and M. Vannucci. 1993. Mangrove ecosystems of Latin America and the Caribbean: a summary. In Lacerda, L.D., Project Coordinator. Conservation and sustainable utilization of mangrove forests in Latin America and Africa regions. International Society for Mangrove Ecosystems and International Tropical Timber Organization Project PD114/90(F). Yokohama, Japan. p:1-42.

Lefebvre, G.; B. Poulin, and R. McNeil. 1994. Temporal dynamics of mangrove bird communities in Venezuela with special reference to migrant warblers. The Auk 111:405415.

López, J.M.; A.W. Stoner; J.R. García, and I. García M. 1988. Marine food webs associated with Caribbean island mangrove wetlands. Acta Científica 2:94-123.

Lugo, A.E. 1980. Mangrove ecosystems: successional or steady state? Biotropica 12 (supplement 2):65-72.

Lugo, A.E. 1981. The inland mangroves of Inagua. Journal of Natural History 15:845-852.

Lugo, A.E. 1986. Water and the ecosystems of the Luquillo Experimental Forest. USDA Forest Service, Southern Forest Experiment Station General Technical Report SO-63. New Orleans, LA. 17 p.

Lugo, A.E. 1990. Fringe wetlands. Pages 143-169 In: A.E. Lugo, M.M. Brinson, and S. Brown, eds. Forested wetlands. Elsevier. Amsterdam, The Netherlands. 
Lugo, A.E. 1994. San Salvador mangroves: an ecosystem under chronic stress. In: L.B. Kass, ed. Proceedings of the 5th symposium on the natural history of the Bahamas. Bahamian Field Station. San Salvador, Bahamas. p:60-63.

Lugo, A.E. 1996. Caribbean island landscapes: indicators of the effects of economic growth on the region. Environment and Development Economics 1(1):128-136.

Lugo, A.E. 1999a. El manglar: un ecosistema al servicio del ser humano. In: S.D. Matteucci; O. Solbrig; J. Morello, and G. Halffter, eds. Biodiversidad y uso de la tierra. Conceptos y ejemplos de Latinoamérica. Ceudeba, Centro de Estudios Avanzados. Universidad de Buenos Aires. Buenos Aires, Argentina. p:361-382.

Lugo, A.E. 1999b. Mangrove forests: A tough system to invade but an easy one to restore. Marine Pollution Bulletin 37(8-12):427-430.

Lugo, A.E.; G. Cintrón, and C. Goenaga. 1981. Mangrove ecosystems under stress. In: G.W. Barret and R. Rosenberg, eds. Stress effects on natural ecosystems. John Wiley and Sons Limited, Sussex, England. p: 129-153.

Lugo, A.E. and S.C. Snedaker. 1974. The ecology of mangroves. Annual Review of Ecology and Systematics 5:39-64.

Luna L., A. 1976. Manejo de manglares en Venezuela. Boletín del Instituto Forestal Latinoamericano 50:41-56.

Luna L., A. 1983. Aprovechamiento de los manglares. Boletín de la Sociedad Venezolana de Ingenieros Forestales 22:18-19.
Medina, E.; E. Cuevas; M. Poop, and A.E. Lugo. 1990. Soil salinity, sun exposure, and growth of Acrostichum aureum, the mangrove fern. Botanical Gazette 151(1):41-49.

Medina, E.; A.E. Lugo, and A. Novelo. 1995. Contenido mineral del tejido foliar de especies de manglar de la Laguna Sontecomapan (Veracruz, México) y su relación con la salinidad. Biotropica 27(3):317-323.

Medina, E.; H. Fonseca; F. Barboza, and M. Francisco. 2001. Natural and man-induced changes in a tidal channel mangrove system under tropical semiarid climate at the entrance of the Maracaibo lake (Western Venezuela). Wetlands Ecology and Management 9:233-243.

Milian P., C. 1997. Restauración de ecosistemas de manglar en Cuba. In: C. Field and D.B. Trauman, editor and translator. La restauración de ecosistemas de manglar. Organización Internacional de Maderas Tropicales y Sociedad Internacional para Ecosistemas de Manglar. Editorial de Arte. Managua, Nicaragua. p:176-186.

Milian P., C.; S. Llorente, and L. Menéndez. 1993. Mangroves of Cuba. In: Lacerda, L.D., Project Coordinator. Conservation and sustainable utilization of mangrove forests in Latin America and Africa regions. International Society for Mangrove Ecosystems and International Tropical Timber Organization Project PD114/90(F). Yokohama, Japan. p:147-154.

Naranjo, L.G. 1997. A note on the birds of the Colombian Pacific mangroves. In: B. Kjerfve, L.D. de Lacerda, and E.H.S. Diop, eds. Mangrove ecosystem studies in Latin America and Africa. United Nations Educational, Scientific and Cultural Organization. Paris, France. p:64-70. 
Odum, W.E. 1982. The ecology of the mangroves of South Florida: a community profile. U.S. Department of Interior. Fish and Wildlife Service. Biological Services Program. FWS/ OBS-81/24. Washington, D.C. $144 \mathrm{p}$.

Olsen, S. and L. Arriaga, eds. 1989. A sustainable shrimp mariculture industry for Ecuador. Technical Report Series TR-E-6. International Coastal Resources Management Project. The University of Rhode Island Coastal Resources Center. Narragansett, RI. 276 p.

Osorio, O. 1994. Proyecto INRENARE/ OIMT al rescate de los manglares de Panama. Revista Forestal Centroamericana 3(9):33-37.

Pauly, D. and A. Yáñez A. 1994. Fisheries in coastal lagoons. In: B.J. Kjerfve, ed. Coastal lagoon processes. Elsevier. Amsterdam, The Netherlands. p:377-399.

Pereira T, M.M. 2000. Manguezais catarinenses, Baía da Babitonga e Rio Tavares: uma abordagem parcial dos atributos ecológicos e econômicos. Dissertation. Oceano-graphic Institute of the University of São Paulo. Brazil. $217 p+$ appendices.

Polanía, J. 1993. Mangroves of Costa Rica. Pages 129-137 In: Lacerda, L.D., Project Coordinator. Conservation and sustainable utilization of mangrove forests in Latin America and Africa regions. International Society for Mangrove Ecosystems and International Tropical Timber Organization Project PD114/90(F). Yokohama, Japan.

Polanía, J. and V. Mainardi. 1993. Mangrove forests of Nicaragua. In: Lacerda, L.D., Project Coordinator. Conservation and sustainable utilization of mangrove forests in Latin America and Africa regions. International Society for Mangrove
Ecosystems and International Tropical Timber Organization Project PD114/90(F). Yokohama, Japan. p:139-145.

Rollet, B. 1981. Bibliography on mangrove research 1600-1975. UNESCO. Paris. $479 \mathrm{p}$.

Rollet, B. 1986. Ordenación integrada de los manglares. Síntesis de siete seminarios nacionales en América Latina. Organización de las Naciones Unidas para la Alimentación y la Agricultura. FO: Misc 86-4. Roma, Italia. $100 \mathrm{p}$.

Sánchez P., H.; G.A. Ulloa D., and R. Alvarez L., eds. 2000a. Hacia la recuperación de los manglares del Caribe de Colombia. Impresos Panamericana. Santa Fe de Bogotá, Colombia. 294 p.

Sánchez P., H.; R. Álvarez L.; O.A. Guevara M., and G.A. Ulloa D. 2000b. Lineamientos estratégicos para la conservación y uso sostenible de los manglares de Colombia. Impresos Panamericana. Santa Fé de Bogotá, Colombia. 81 p.

Sanoja, M. 1992. Wetland ecosystems and the management of cultural heritage. Pages 66-73 In: A.E. Lugo and B. Bayle, eds. Wetlands management in the Caribbean and the role of forestry and wetlands in the economy. USDA Forest Service. Southern Forest Experiment Station. New Orleans, LA.

Sheil, D. 2001. Conservation and biodiversity monitoring in the tropics: realities, priorities, and distractions. Conservation Biology 15:1179-1182.

Snedaker, S.C. and P.D. Biber. 1997. Restauración de manglares en los Estados Unidos de América. In: C. Field and D.B. Trauman, editor and translator. La restauración de ecosistemas de manglar. Organi- 
zación Internacional de Maderas Tropicales y Sociedad Internacional para Ecosistemas de Manglar. Editorial de Arte. Managua, Nicaragua. p:187-208.

Suman, D. 1994. Legislación y administración de los manglares de América Central. Revista Forestal Centroamericana 3(9):6-12.

Szelistowski, W. 1990. Importance of mangrove plant litter in fish food webs and as a temporary, floating habitat in the Gulf of Nicoya, Costa Rica. Dissertation. University of Southern California. $288 \mathrm{p}$.

Thom, B.G. 1967. Mangrove ecology and deltaic geomorphology, Tabasco, Mexico. Journal of Ecology 55:301343.

Thom, B.G. 1982. Mangrove ecology - a geomorphological perspective. In: B.F. Clough, ed. Mangrove ecosystems in Australia: structure, function and management. Australian Institute of Marine Science and Australian National University Press. Canberra, Australia. p:3-17.

Tomlinson, P.B. 1986. The botany of mangroves. Cambridge University Press. Cambridge. 413 p.

Trejo T., J.C., R. Durán, and I. Olmsted. 1993. Manglares de la Península de Yucatán. In: S.I. Salazar V. and N.E. González, eds. Biodiversidad marina y costera de México. Comisión Nacional Biodiversidad y CIQRO. México. p:660-772.

Turner, R.E. 1989. Factors affecting the relative abundance of shrimp in Ecuador. In: S. Olsen and L. Arriaga, eds. A sustainable shrimp mariculture industry for Ecuador. Technical Report Series TR-E-6. International Coastal Resources Management Project. The University of Rhode
Island Coastal Resources Center. Narragansett, RI. p:121-139.

Twilley, R.R. 1989. Impacts of shrimp mariculture practices on the ecology of coastal ecosystems in Ecuador. In: S. Olsen and L. Arriaga, eds. A sustainable shrimp mariculture industry for Ecuador. Technical Report Series TR-E-6. International Coastal Resources Management Project. The University of Rhode Island Coastal Resources Center. Narragansett, RI. p:91-120.

Twilley, R.R., R.H. Chen, and T. Hargis. 1992. Carbon sinks in mangroves and their implications to carbon budget of tropical coastal ecosystems. Water, Air, and Soil Pollution 64:265-288.

Twilley, R.R., A. Bodero, and D. Robadue. 1993. Mangrove ecosystem biodiversity and conservation in Ecuador. In: C.S. Potter, J.I. Cohen, and D. Janczewski, eds. Perspectives on biodiversity. American Association for the Advan-cement of Science. Washington, D.C. p:105-127.

Twilley, R.R., R.R. Godfried, V.H. Rivera M., M. Montano A., J.M. Valdivieso, and A. Bodero. 1998a. An approach and preliminary model of integrating ecological and economic constraints of environmental quality in the Guayas River Estuary, Ecuador. Environmental Science and Policy $1: 271-288$

Twilley, R.R., V.H. Rivera M., R. Chen, and L. Botero. 1998b. Adapting an ecological mangrove model to simulate trajectories in restoration ecology. Marine Pollution Bulletin 37:404-419.

Valiela, I. and M. L. Cole. 2002. Comparative evidence that salt marshes and mangroves may protect seagrass meadows from land-derived nitrogen loads. Ecosystems 5:92-102. 
Williams, K., K.C. Ewel, R.P. Stumpf, F.E. Putz, and T.W. Wokman. 1999. Sealevel rise and coastal forest retreat on the west coast of Florida, USA. Ecology 80:2045-2063.

Windevoxhel, N. 1994. Valoración económica de los manglares: demostrando la rentabilidad sostenible. Caso héroes y mártires de Veracruz, Nicaragua. Revista Forestal Centroamericana 3(9):18-26.

Wunderle, J.M. Jr. and R.B. Waide. 1993. Distribution of overwintering Nearctic migrants in the Bahamas and Greater Antilles. The Condor 95:904-933.

Wunderle, J.M. Jr. and R.B. Waide. 1994. Future prospects for Nearctic migrants wintering in Caribbean forests. Bird Conservation International 4:191-207.
Yáñez A., A. and A.L. Lara D., eds. 1999. Mangrove ecosystems in tropical America. Instituto de Ecología. A.C. Xalapa, México. IUCN/ORAMA, Costa Rica; NOAA-NMFS-USA. Silver Springs, MD. 380 p.

Yáñez A., A., A.L. Lara D., and J.W. Day Jr. 1993. Interactions between mangrove and seagrass habitats mediated by estuarine nekton assemblages: coupling of primary and secondary production. Hydrobiologia 264:1-12.

Yáñez A., A., A.L. Lara D., and D. Pauly. 1994. Coastal lagoons as fish habitats. Pages 363-376 In: B.J. Kjerfve, ed. Coastal lagoon processes. Elsevier. Amsterdam, The Netherlands. $\diamond$

$1 \quad$ International Institute of Tropical Forestry. USDA Forest Service. PO Box 25000. Río Piedras, PR 009285000.c.e.: alugo@fs.fed.us.

Manuscrito recibido el 22 de abril de 2002.

Aceptado el 14 de mayo de 2002.

Este documento se debe citar como:

Lugo, A.E. 2002. Conserving Latin American and Caribbean mangroves: issues and challenges. Madera y Bosques Número especial:5-25. 
Esta página fue dejada en blanco intencionalmente. 